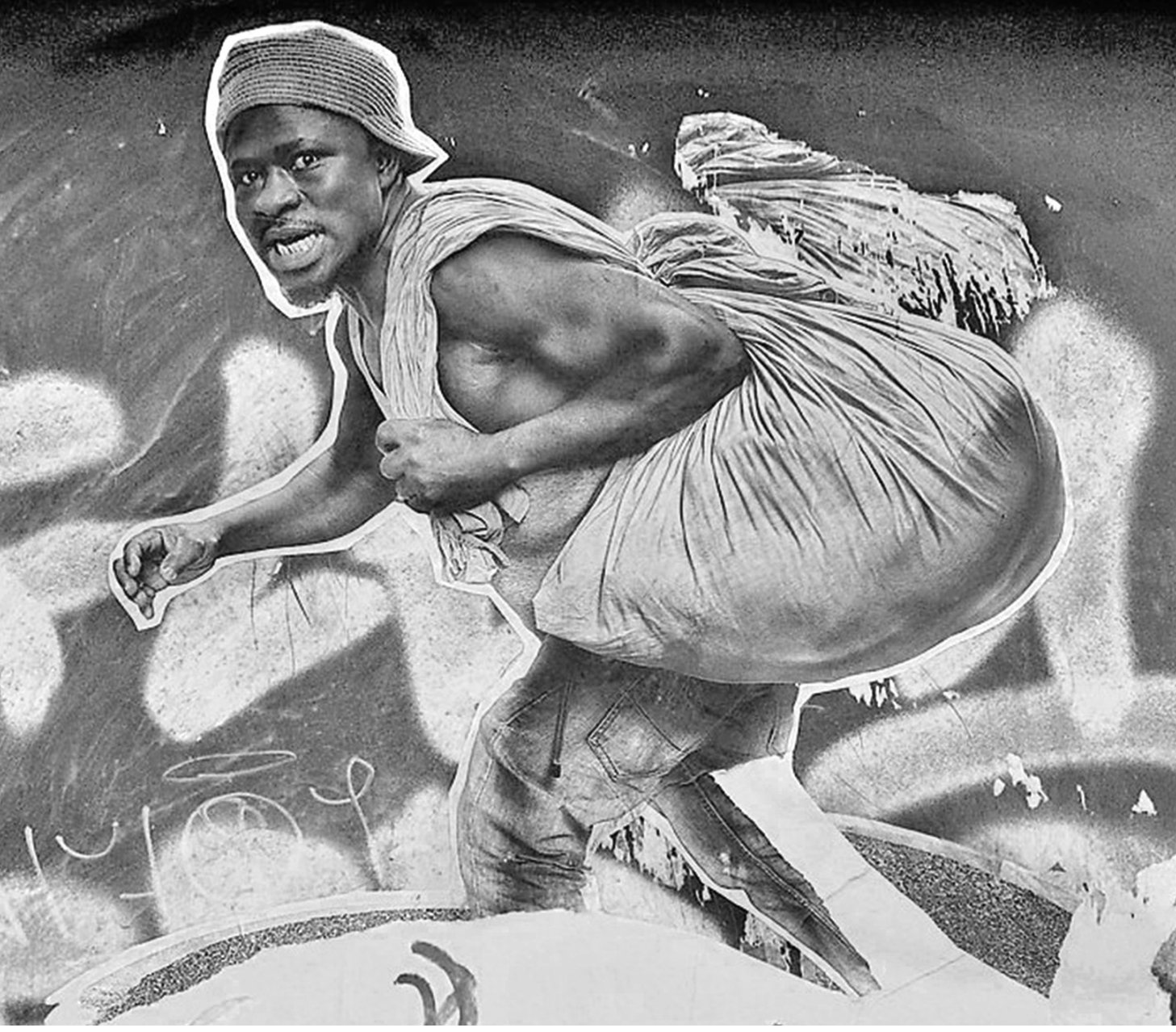

AIBR

Revista de Antropología Iberoamericana

www.aibr.org

Volume 16

Number 2

May - August 2021

Pp. $249-264$

Madrid: Antropólogos Iberoamericanos en Red. ISSN: 1695-9752

E-ISSN: 1578-9705

\section{Public Space and its Discontents. Informality} and Urban Conflict

\section{Horacio Espinosa}

Observatorio de Antropología del Conflicto Urbano

\section{Marta Contijoch}

Departamento de Antropología Social; Facultad de Geografía e Historia; Universidad de Barcelona

Submitted: October 21, 2020

Accepted: October 28, 2020

DOI: 10.11156/aibr.160203e

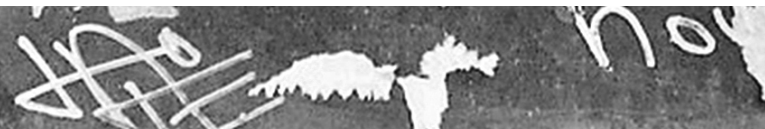




\section{ABSTRACT}

Considering the critical positions regarding the normative ideal of public space, the objective of this special number and its introduction is to point out the central contradictions within the concept of public space as spatially placed ideology, which have transformed the streets into allegedly pacified, sanitized territories. We have developed this critical conception of public space through certain practices that, defined as "informal", are crucial to understand the necessarily conflictive nature of what is urban, and that a notion as "public space" tries to hide or disguise as consensus.

\section{KEY WORDS}

Informality, public space, urban conflict, urban anthropology, right to the city.

\section{EL ESPACIO PÚBLICO Y SUS DISCONFORMES. INFORMALIDAD Y CONFLICTO URBANO}

\section{RESUMEN}

Partiendo de una perspectiva en oposición al ideal normativo del espacio urbano, el objetivo de este monográfico y de esta introducción es señalar aquellas contradicciones centrales en el concepto de «espacio público» en tanto ideología espacialmente situada que ha transformado las calles en territorios pretendidamente desconflictivizados e higienizados. Es así como ofrecemos este planteamiento crítico con la ideología del espacio público a partir de ciertas prácticas que, definidas como «informales», son determinantes para entender la naturaleza esencialmente conflictiva de lo urbano, y que una noción como «espacio público» intenta disimular o disfrazar de consenso.

PALABRAS CLAVE

Informalidad, espacio público, conflicto urbano, producción del espacio, derecho a la ciudad. 


\section{Introduction}

This special number aims to contribute to the discussion on the forms taken by the relationship between public space, informality, and urban conflict in different contexts. It does so on the basis of the examples presented in the six papers included in this number. Part of this discussion comes from the debates opened in de panel Informality and urban conflict: critical perspectives from the Global South organised during the $2^{\text {nd }}$ edition of the AIBR Conference (Barcelona, 2016). The notion of "informal" is often evoked when facing the impossibility of defining, delimiting and, therefore, controlling those expressions of urban life that question what Lefebvre called conceived space, that is, the representation of urban space developed by supposed experts in cities (Lefebvre, 2013: 96-104). Through an often reductionist theoretical corpus, sometimes directly adverse to what, perhaps, should simply be called self-organization and appropriation of the city by its own users, informality is pointed out as an additional way of urban anomie.

This alleged anomaly would highlight the institutional deficiency concerning the entities called on to provide, especially underprivileged sectors, with "formal" organizational procedures that suit their supposed needs. The emergence of informal elements shows the Institutions' thwarted intentions of eradicating inequality and its urban expression; displaying at the same time the resistance, on the grounds of distrust or antagonism, coming from the marginalized population itself, to being integrated into some sort of system that is normalized and, thus, normalizing.

One of the first uses and theorizations about "informal" as a category could be found in the work of anthropologist Keith Hart (1973), understood in the framework of his studies on urban labour in Ghana, about the link between certain productive activities carried out in public urban spaces and their lack of restraint by state regulations. It is to this type of labour alegality that he refers to with the term "informal labour". In the field of Economic Anthropology, other authors would point out some non-legal characteristics insufficiently considered in Hart's analysis, such as the "temporary and impermanent character" of these types of jobs (Martínez, 2009: 38), as well as the aspects associated with the lack of labour rights and adjacent forms of job insecurity (Valenzuela, 2003).

Nevertheless, in a wider sense, informal work, and through it all kind of informality, will be analysed regarding its relationship with the legal structure that overlooks it or, even acknowledging it, sanctions it. In this sense, we can say that what is "informal" is understood as an activity that develops outside the scope of state regulation (Mead and Morrison, 1996; 
Portes, Castells and Benton, 1989: 12; Savedra and Chong, 1999: 99). Likewise, if informality is traditionally understood as a synonym of informal work, it could be said, in a reductionist fashion, that informal activities would be all the productive ones that do not pay taxes but that are expected to do so in case they become formal, from a point of view that would ignore all other legal aspects except for having a business license and paying taxes. Thus, few would question the "formality" of a legally founded company, however much it, in the undertaking of its productive activity, breaks codes and consumer rights protection laws, environmental regulations, work rights or even public space regulations, an aspect in which "formal" businesses seem to do no wrong in the public eye. Furthermore, we notice a tendency to take the legal angle as reference, interpreting "formal" and "informal" as absolute, indivisible, and stagnant categories.

This tout court demarcation between "formal" and "informal" has worked as a distinguishing mark marginalizing urban practices that do not have a State endorsement and, therefore, find themselves restricted, punished or persecuted. It is in this negative regard where we should look for the roots of prejudice and persecution against informality: it is perfunctorily assumed that, if an activity does not comply with one regulation — basically, having a permit - it automatically ceases to comply with the rest. Following this logic, for instance, a man selling fruit on the street would be seen as irregular, and even children playing football at a random park would. The State's unquestionable authority over the street - associated to the notion of public space as a space belonging to the people - implies that all activity unregulated by it becomes inherently disorganized, which does not comply with any regulation whatsoever and is at the heart of a whole range of trouble and social disorders. On the contrary, it is assumed that when a business bears a State endorsement, it complies with all the regulations, and thus, this activity is necessarily beneficial for society, or at least not a harmful one.

Only normalized activities confer the subject who works in them a certain symbolic value before society, while informal ones, once again, do not seem to be contributing anything socially significant, and are even considered as a burden. Mike Davis, in his Planet of Slums (2006), refuses to see in informality an answer to poverty, considering it instead among its causes, which would be nothing more than a refined way of making poor people responsible for their own situation. Davis seems to deny the underprivileged any innovative capability, be it through self-making or through economic networks that escape state regulations. He makes a parody of the poor as absurd agitators of internecine wars, or points at 
them as the reason for "social capital" reduction, as well as for diluting "help and solidarity networks essential for the survival of the underprivileged". He even finds a way to describe informality as a "museum of exploitation" (2006: 241-247).

It can be noticed in this kind of approach what, paraphrasing Michael Taussig (2015), we could describe as a certain state fetishism, symptom of a particular predominant outlook in parts of the institutionalized leftwing mind-set, which assumes that everything that in one way or another is "left out" of the scope of state supervision inevitably turns into pasture for neoliberal ventures. This sort of state-centrism prevents them from seeing the complexity around urban informality, as well as the multiple forms of association between the formal and the informal sectors. It mainly incurs the mistake of taking informality as an all-encompassing classification, as if the same "substance" constituted a sweatshop, street market sales, a gang of children building a makeshift structure for a game on a plot of land, the construction process of a slum or a self-managed motorcycle taxi service.

Now that it has been unveiled as problematic, would not it be pertinent to abandon or to rethink the very category of informality? In this sense, we think that, instead of denying it, we should recognize its status as a central part of Urban Anthropology, remaining critical about some of its interpretations. From our standpoint, urban informality would emerge as the most vulnerable sectors organize themselves through a series of practices that seem to be at first sight spontaneous, despite being, in fact, deeply organized and subject to their own forms of institutionalization and taxation, and not always so different from their hegemonic counterparts in the formal sphere. They are usually carried out by social actors coming from the lower steps of the social pyramid, or from its margins: poor, immigrants, prostitutes, children, and young people. These groups use the streets as a shelter, a playground or means of subsistence. They organize in clans, families, gangs, crews, and other forms of non-bureaucratic social structuring. Their relationship with the State is ambiguous, but not necessarily non-existent. The rules they follow are not usually in writing, and familiarization with them is more of a learned or conveyed know-how than a series of standardized and written regulations, guidelines, or instructions.

\section{The space issue in the sociology of the "informal sector"}

Although it would be somehow counterintuitive to think that there can be a discussion about cities and what is characterized as urban without mentioning space, it is Manuel Castells who, in The Urban Question 
(2014), claims precisely that space has no value beyond being a product of "the social forces" (see also AlSayyad, 2004: 26). Thus, and as a reaction to prevalent urban sociological theories, in which echoes of the first half of the twentieth century could still be heard, when the Chicago school treated urban matters as "human ecology", Castells (2014: 142-145) wrote a harsh critique of this theoretic branch's tendency to homeostatic interpretations over conflictive ones present in classics such as The City (Park, Burgess and McKenzie, 1992), in which their excessive "spatial analysis" ignores "structural laws of production", so that, according to the sociologist, every theory about the "urban mode" is nothing more than Ideology, "left-wing" or "right-wing”, but "Ideology" after all (Castells, 2014: 107).

According to Castells, the city-shape is foreshadowed in the social structure, and even the latter is not more than the result of the historical deployment of economic production methods and, therefore, "there is no specific theory of space, but rather just an extension and detailing of the theory of social structure" (2014: 152). Opposite to this stereotyped and somehow mechanistic Marxist structuralism, Henri Lefebvre would claim, in The Production of Space, "there are no social relations without space, as there is no space without social relations" (2013: 14); brilliant in its simplicity and clarity, this phrase could very well be a condensation of critical geography epistemology and new-wave urban anthropology.

A little earlier, in The Urban Revolution, Lefebvre rewrites the Marxist modes of production, as "modes of thinking, acting, living" (1976: 47). Hence, the "urban mode" would not be reducible to the industrial mode of production, despite urban society being "born from industrialization" (:1). Castells (2014: 110) ironizes Lefebvre and what he understands as social "spontaneity", product of a "libertarian and abstract" understanding of what is urban, which in any event would betray a certain anarchist aspect in the Frenchman, this being sort of an anathema for our sociologist.

Opposite the Lefebvrian urban category, Castells reduces the shapes of the city to economic classes: production, as "spatial expression of the means of production" and consumption, as "spatial expression of the workforce". This reasoning on the means of production leaves him puzzled when faced with anything that is not productive activity, which he calls, in an antithesis of sociological imagination, "the non-work element," supposedly lacking a "specific spatial expression" (2014: 154). Anything that cannot be reduced to the pair production-consumption is defined in negative terms, as a non-existence. The city beyond office buildings, garages, factories, shops, and malls is reduced to a huge empty lot. 
This anti-spatial and work-centric understanding of what is urban in Castells' writings is paramount to understand why sociology's hegemonic perspective on the category of "informal" relates it to work. Accordingly, from the seventies and until today, prevalent sociological theories studied the "informal sector" or the "informal economy" (Bromley, 1978; De la Garza, 2011; Martínez, 2009; Moser, 1978; Pérez Sáinz, 1991), a perspective that only considers the spatial issue incidentally, and the public space issue even more so. Paraphrasing Lefebvre, we could say that informality, as a perspective on an urban way of thinking, acting and living, has been excluded from hegemonic analyses.

\section{Informality and state fetishism}

Cathy Rakowski (1994) carried out an important systematization work related to the perspectives on the informal economy issue, especially by Latin American authors or those focusing on Latin America, an authentic focal point for studies about the informal sector. Through her analysis, Rakowski described two great schools: "structuralism" and "legalism". The former would comprise researchers linked in some way or another to Marx-inspired sociology. The latter would have Hernando De Soto and other micro-enterprise theoreticians with neoliberal tendencies, more likely to see informal work as a product of entrepreneurs in action.

Among the many contributions made by structuralism, one of the greatest has been an analysis of informal economy as a sector whose relationship with the established economy is not necessarily antagonistic. For these researchers, informality would not be on the margins, but rather at the core of economic processes and, therefore, closely linked to political and economic institutions. Thus, the State would not always keep an antagonistic relationship with it but would be, at the least, ambiguous as to certain informal activities, or even, in particular situations, would become its "ally". It is in this sense that we must point out the functional relationship between what is informal "and the political and economic institutions that it allegedly undermines" (Portes and Haller, 2004: 5).

On the contrary, for Peruvian De Soto (1989), informality would represent capitalism's authentic face, popular and without state intervention. It would be, even, a real revolution against "the rigidity of "mercantilist" States predominant" (Portes and Haller, 2004: 10). Nevertheless, it is not just in the right-wing sector where we find this polar, dualist perspective on what is formal/informal. Standpoints such as Veronica Gagós (2015) are a curious case of authentic specular dialogue with De Soto. According to Gagó, informal economy could be characterized as "self- 
made neoliberalism" (2015: 25) and it would undermine, by itself, unions and other social institutions that have traditionally helped mitigate inequality, contributing to the welfare state structure in Western democracies.

Gagó and De Soto perspectives are the product of a widely spread fallacy, originating in the thesis that claims that capitalism tends to advance in the absence of the State. David Harvey (2007: 26) claims that, on the contrary, this "ridiculous idea" goes against the evidence that "the Nation-state is currently more dedicated than ever to creating a climate for investment". On the contrary, this relationship between informal sectors and State would evidence the permeability of both sectors: "The fact that the State does not fulfil the role of a regulating agent means that it is at the mercy of market forces and that formal economy does not exist", claim Portes and Haller (2004: 21). However, the big paradox in strict regulations in the informal sector is that the stricter the regulations, the better the chance of a big sector of the economy "falling" into informality. The more rules, the more chances to break them. As Lomnitz points out, "order creates disorder. Formal economy creates its own informality" (1988: 54).

\section{Urban informality: from the means of production to the produc- tion of space}

Since the end of the nineties, especially in the last decade, more than a few authors, from different disciplines in the Social Sciences, considered it relevant to approach other issues besides production, like the appropriation of public space, social control, political resistance or subalternity relationships (Cross, 1998; De la Garza, 2011; Espinosa, 2017b; Porras Bulla, 2016; Wacquant, 2007 to cite only some examples), fundamental when discussing labour informality. But the most interesting achievement, to us, was managing to diversify perspectives, methodologies and disciplines interested in urban informality. It could be said that the work-centric perspective that characterized the analysis of the issue for several decades has made way for more polycentric views, so it would be a mistake to continue to identify urban informality with the so-called informal sector.

Contrary to what institutional urbanism does - forcing an authoritarian order in the city from the top - we can understand urban informality as a way of creating space starting from its foundations, in the way that Solomon Benjamin has named "transformative urbanism" (2008: 18). 
They are practices that do not start with a project or plan created by technicians but rather constitute themselves through operative creativity as the necessary know-how, a socialization of knowledge through cooperation and experience. Individuals who, in one way or another, took part in this informality would be, in a way, authentic urban bricoleurs, following what Lévi-Strauss (1988) called "science of the concrete". A bricoleur, unlike an urbanist, establishes a dialogue with the materials he has on hand, rather than a project monologue; an image equally contrary to the idea of a creative individual who builds cities "from scratch", implicit in the smart cities speech, as part of a neoliberal project that restores the idea of an "auteur city", be it by a designer, an urbanist or an architect.

A study by Mario Barbosa (2006) in Mexico City analyses the concept of "path" as a frame to understand the popular division of the city, conceived by informal street workers alongside the official bureaucratic division. Paths are, thus, defined by the inhabitants of the city through the distribution of informal commerce spaces throughout urban geography (2006: 02), generating a kind of counter-identity, opposed to the rationalist grid imposed by authorities. Public space appropriation in neighbourhoods takes place through the setup of street stands, which work as boundaries that break the public/private dichotomy. The popular determination of these paths stems from the informal commercial centres where the functions of workplace and household overlap.

\footnotetext{
We considered that this model -in which there were not any precise barriers between the inside and the outside, between public and private, and in which workplace and transit space blended- enabled a greater level of interaction, of solidarity among peers, and therefore, more opportunities for survival in adverse conditions (2006: 08).
}

This example takes us to another characteristic of informality as "urban porosity", a concept developed by Walter Benjamin after a trip to Naples with Asja Lacis. In his essay "Naples" (1978) he gathers his impressions on the city, described by Benjamin in terms of its spatial and temporal "porosity". The voluptuousness of southern street life impresses the couple, especially details surely considered ordinary by the locals. The arcs delimiting commercial passages, for example, are an object of fascination for them, as they generate the impression of them being enclosed spaces, simultaneously filtering in daylight, opening a private space to the sky, but also merging the city with a space for consumption.

"Porosity" does not end within the arcs, but it extends to the forms of the entire city, a metaphor showing communication, interdependence and space transmutation, in the way in which the different orders combine and 
connect with each other. In a way, according to the couple - admirers of Lukacs' works, which describe capitalism in terms of dehumanization processes - Naples makes experiencing a less homogeneous urban modernity possible, in contrast with the views of a certain orthodox Marxism. The improvisation in Neapolitan street life filters into its institutions. Laws do not seem to be very clear and there is confusion as to who must fulfil the central role in the decision-making structure of the city, which is split between the mafia (the Camorra), the Church and Mussolini's fascist State, only just established in Italy. This "porosity" is also present in a temporal sense and, for instance, it is difficult to know for sure whether the buildings are in the process of being constructed or decaying and becoming ruins: "it eludes the print of what is conclusive" (Benjamin, 1978: 165-166).

Similarly to the experience of Neapolitan commercial passages, informal life in contemporary cities - especially, but not exclusively, those in the "Global South" — includes the light's fluffy quality, no longer thanks to transparent glass, but in the even more literal permeability of the fragile structures of stands, shacks, stalls, tents, trade fairs, "tianguis" (open-air markets) and other structures that, with their rocky setup, leave small or big pores through which light filters in, generating a strange atmospheric effect very like chiaroscuro. Not only is informal architecture porous but so is the intertwining among what is public and private, what is ludic, economic, as well as what concerns the family and work. The intensity of informal life affects the commercial trade with personal considerations, but the opposite is also true, that: "each attitude or private act is permeated by community life" (Benjamin, 1978: 167).

Informal structures and subjects, besides being porous, are usually nomad. Anthropologist Maria Teresa Salcedo (2000) produced a revealing ethnography about waste collectors in Bogotá. Salcedo describes fieldwork as a "physical practice" in which successive acts of representation of the other occur, of the researcher themselves as "ethnographic data" and of the city surface on which the ethnographic relation is registered, thus creating a "transient anthropology" (2000: 157-158). The street culture Salcedo describes is defined by communities — "el parche" (a group of friends) — in a trajectory — "el viaje" (a journey) — which, though it holds the purpose of waste collection, trash, cardboard, bottles, cans, etcetera, assisted by an improvised cart, but powered by the use of drugs, it also constitutes, in a way, an "dreamlike journey":

The journey in itself is a physical transfer, a real movement through a route to get to a particular territory, but it also recalls an oneiric experience during which the streets turn into some kind of cipher decoded by the people who are familiar with the different paths and trajectories in a predetermined map on 
the urban level, like a dream fabric to the child or the peasant arriving in the city for the first time (2000: 159).

Street ethnography becomes a route layout, simultaneously geographic, physical and symbolic. The territory is not just a map, but also a texture, a space on which to write and the body on which the territory is imprinted. To Salcedo, the dustmen's own texture is the "smooth space" one - nomad - opposite to the "striated space" one — sedentary conceptualized by Deleuze and Guattari (2004). However, we do not speak about different textures, but opposite ones. The nomad junkman rewrites the official city mesh as if he were pulling towards him "that fasten the roads to the land" (Salcedo, 2000: 160). That is, we refer to the dialectic territorialization-deterritorialization that Deleuze and Guattari recognized as a possibility in the smooth eastern game Go, contrary to striated chess (2004: 361).

\section{Informality, public space and conflict}

It is not strange that the so-called public space is frequently denied to those who carry out practices classifiable under what we described as the informal sector. As a way of conferring morality to what is topological (Delgado, 2011: 19), public space would be defined by a certain "must be" that would imply, at the same time, a know-how-to-be based on self-discipline in communal places, to adapt it to the principles of civility and good citizenship that are supposed to govern it. Thus, the notion of public space itself would be paradoxical, as it would be funded, apparently, in equality, but it would operate by excluding those who, for some reason, would be considered inacceptable for not reaching the moral rank assigned to the space. In this sense, we could talk about public spaces as "all those areas that are open and accessible to every member of the public in a society, in principle, but not necessarily in practice" (Neal, 2010: 1). Therefore, it is fitting to question: who are "everyone" when it is claimed that public space is for "everyone"?

Subject to its funding normative ideal, public space is the product of a particular political imaginary, more than an empirically verifiable place. Conceived as a sphere for the conciliation of antagonist interests and identities, public space appears insistently represented as the stage for a negotiation between hypothetical equals that is constantly renewed, and the speech that legitimizes it — even raising it to a "valued" category — is structured in such a way that it simultaneously hides and theoretically resolves the contradictions that happen in its physical manifestation, that 
is, the street. Deep social conflicts repeatedly presented in the practical reality of concrete spaces (Mitchell, 1995) are represented as a consequence of particular urbanistic formulas, in the same way, the solution to such problems about public space resides in the consensual character of the public sphere concept formulated by Habermas (1981), the origin of which would be directly associated, regarding its spatialization, to the bourgeois civil society ideal.

In effect, although Habermas did not place the public sphere in specific spaces, it is possible to historically identify which places he was referring to, through his own examples: literary clubs, philanthropic associations, cafés, tea salons and newsrooms that covered the European Enlightenment. Nevertheless, it is fitting, in the first place, to point out the arbitrariness in the public/private division in Habermas' theory, the historical period and place he wants to enthrone - England, France and Germany in the second half of the $18^{\text {th }}$ century - and its universalization as myth. It is to these "public" spaces meant to be raised to universal categories that Nancy Fraser (1990) refers critically. On the one hand, a certain "open and free" quality is claimed for these spaces, ignoring that, in effect, they were places for a privileged sector, exclusive, and, thus, restricted. These places, which in practice were not for everyone, even if they were more or less open, in actuality belonged to citizens with a very concrete profile: bourgeois, male, urban, educated, more or less cultured and relatively wealthy.

Hand in hand with this liberal ideology presumption stating that public space would be equally open and accessible to every member of the same "public" — in the sense that configures self-accountable individuals, imbued with civic virtue - the notion of public space is imbricated with Modernity's political project, along with other fundamental ideas in the same civilizing ideology as democracy and citizenship. In a way, public space is conceived as the ideal place to exercise both, with the condition of citizenship as the only requisite to obtain access rights to what we could describe as the democratic public sphere, eliminating, therefore, any other boundary or structural barrier before the participation in public affairs. These abstract universal principles articulate the majority of the debates about access rights to material public space (Neal, 2010; Staeheli and Thompson, 1997).

This inoculation of ideological elements taken from bourgeois democratic idealism into the particular street stage roughly translates to what Jean-Pierre Garnier (2000) and, more recently, Manuel Delgado (2016) would call "citizenism", that is, the raising to a status of ideology of the middle class delusion about a conflict-free space, pacified and civilizing, from which every real social inequality has disappeared, overcome by the argumentative skills of rational individuals who are capable of getting 
over their differences through dialogue. All of that in conformity with the ideals of liberal democracy, personified in the prototype of the freethinking citizen, appropriately informed and educated.

However, the street, with its tendency to become the setting for the failures and incompatibilities that serve as building blocks for social reality, does not seem to be the appropriate space to plant the mythical public sphere of liberal thought. Thus, those who intend to transform the street into public space, understood from the standpoint of Habermas' consensus theory, will find themselves facing the quite significant problem of having to behave as if inequality did not exist in society and, therefore, as if it did not exist on the street, either. Only that illusion of appeasement of real social relations and their inevitably conflictive quality can make that street transform into what must be according to the ethical horizon that has possessed it without its consent. When we put the coercive forces of the State in service of this ideal, we obtain control technologies directed at forcing users in public places to behave according to what the normative ideal of a democratic mystique wishes for and demands.

This space both genuinely and legitimately "public" would gather the democratic command that citizens would entrust to the Administration in order to guarantee their right as beneficial owners of urban space (Kohn, 2004). However, there are many examples that contradict this official definition, especially if we consider the effective opposition between what is public and the existent procedures to secure it for private benefit. The public-private relationship constitutes the context for ideological structural tensions in public space, directly connecting the dominance of particular interests over the common good in the city's "public" places (Di Masso, Berroeta and Tomeu, 2017: 74). In effect, as Lefebvre would again expound (2013: 407), in a capitalist city there would not be such a thing as "public space", because everything in it is "private space", in other words, privatized: the entire space is treated according to the model of private company, private property and family (Engels, 1976).

This privatizing tendency of alleged public space is part of the growing commodification in cities through the creation of "city brands", which carries with it the generalization of spatial domains that generate control processes under a neo-hygienist speech (Espinosa, 2017a), a framework for private interests posing as public. Equally, control and surveillance devices are installed more and more frequently, a culture of fear is politically encouraged by the media in the streets, territorial markers and defensible spaces proliferate (Newman, 1972), or profitable urban design criteria is imposed over the needs, wishes and demands of the people using the designed urban space every day. 
The result is a narrow concept of public space that disguises its de facto conditions as private space: its access rules, the origin and nature of its control over its usufruct, individual and collective behaviours sanctioned for being "inappropriate" and the exercise of usage norms that imply the active or passive exclusion of awkward presences from certain places, in a way that the average consumer is protected from a "threatening Other" on account of their "race", social class or any other social stigmatization criteria. The informal category is built, thus, in the centre of a negative speech, and proves the futility of a public space for the "quality" of which most citizens are unacceptable, as they exhibit the presence of a poverty and inequality that, following the public space ideal, should not exist, or at least should not be visible. In order to make the utopia of public space true - aseptic, clean, kind, safe — laws, norms and ordinances are deployed to keep in line or expel any "inappropriate" takeover attempt; in so doing, they persecute, ban and sanction the transgressors of an ideal order that reality keeps denying.

In conclusion, from our perspective, conflict and reactions are prime movers for life in the streets, a natural territory for the manifestation of the conquest and upholding of the right to the city, understood in Lefebvre's terms: the right to urban life, including the right to generate and then struggle, out there, against hardships or privation, to deploy every antagonistic option or to practice non-standardized procedures from outside the logic of political or mercantile benefit. The right to the city necessarily includes the possibility of turning urban space truly public — that is, accessible to anyone and for anything - a space that tags as "informal" what are mere expressions of social self-management, manifestations of the subjugated people's insolence, or evidence of how it is impossible to control everything.

\section{References}

AlSayyad, N. (2004). Urban informality as a 'new' way of life. In Urban Informality: Transnational Perspectives from the Middle East, Latin America, and South Asia. A. Roy y N. AlSayyad, Eds. Lanham: Lexington Books.

Barbosa, M. (2006). Rumbos de comercio en las calles: fragmentación espacial en la ciudad de México desde comienzos del siglo XX. Scripta Nova. Revista electrónica de Geografía $y$ Ciencias Sociales. Vol. X, 218(84). In: http://www.ub.edu/geocrit/sn/sn-218-84.htm. Benjamin, S. (2008). Urbanismo transformativo o sobre cómo Walter Benjamin desbarata el capital imperial paseando por ciudades ocupantes. In Post-it City. Ciudades Ocasionales. A. Petti et. al. Barcelona: CCCB. 
Benjamin, W. (1978) [1925]. Naples. In Reflections: Essays, aphorisms, autobiographical writings. New York: Harcourt Brace Jovanovich.

Bromley, R. (1978). Introduction - The Informal Sector: Why is it Worth Discussing? World Development, 6(9-10): 1033-1039.

Castells, M. (2014) [1972]. La cuestión urbana. México, D.F: Siglo XXI.

Cross, J. (1998). Informal politics: Street vendors and the State in Mexico City. Stanford University Press.

Davis, M. (2006). Planet of slums. London, NY: Verso.

De la Garza Toledo, E. (Coord.) (2011). Trabajo No Clásico, Organización y Acción Colectiva, Tomo I. Ciudad de México: Universidad Autónoma Metropolitana-Iztapalapa, Plaza y Valdés.

De Soto, H. (1989). The other path. New York: Harper \& Row.

Deleuze, G. and Guattari, F. (2004) [1980]. Mil mesetas. Capitalismo y esquizofrenia. Valencia: Pre-textos.

Delgado, M. (2016). Ciudadanismo. La reforma ética y estética del capitalismo. Madrid: La Catarata.

Delgado, M. (2011). El espacio público como ideología. Madrid: La Catarata.

Di Masso, A.; Berroeta, H. and Vidal, T. (2017). El espacio público en conflicto: coordenadas conceptuales y tensiones ideológicas. Athenea Digital, 17(3): 53-92.

Engels, F. (1884) [1976]. El origen de la familia, la propiedad privada y el estado. Moscú: Editorial Progreso.

Espinosa, H. (2017a). Les vertus de la violence. La légitimation d'un projet de rénovation urbaine par le néo-hygiénisme. Espaces et sociétés, 3: 173-186.

Espinosa, H. (2017b). El mercadillo rebelde de Barcelona. Prácticas antidisciplinarias en la ciudad mercancía. Quaderns-e de l'Institut Català d'Antropologia, 22(1): 67-87.

Fraser, N. (1990). Rethinking the public sphere: A contribution to the critique of actually existing democracy. Social Text, 25-26: 56-80.

Gagó, V. (2015). La razón neoliberal: economías barrocas y pragmática popular. Madrid: Traficantes de sueños.

Garnier, J.P. (2000). Le nouvel ordre local. Gouverner la violence. Paris: L'Harmattan.

Habermas, J. (1981) [1962]. Historia y crítica de la opinión pública. La transformación estructural de la vida pública. Barcelona: Editorial Gustavo Gili.

Hart, K. (1973). Informal income opportunities and urban employment in Ghana. The Journal of modern African studies, 11(1): 61-89.

Harvey, D. (2007) [2000]. La reinvención de la geografía. In Espacios del capital. Hacia una geografía crítica. Madrid: Akal.

Kohn, M. (2004). Brave new neighborhoods. The privatization of public space. Nueva York: Routledge.

Lefebvre, H. (2017) [1968]. El derecho a la ciudad. Madrid: Capitán Swing.

Lefebvre, H. (2013) [1974]. La producción del espacio. Madrid: Capitán Swing.

Lefebvre, H. (1976). La revolución urbana, Madrid: Alianza.

Lévi-Strauss, C. (1988) [1964]. El pensamiento salvaje. México, D.F: Fondo de Cultura Económica. 
Lomnitz, L. (1988). Informal Exchange Networks in Formal Systems: A Theoretical Model. American Anthropologist, 90(1): 42-55.

Martínez, U. (2009). Economía informal e informalización de la sociedad. Inmigración, derechos políticos y sociales. In Economía informal y perspectiva de género en contextos de trabajo. Barcelona: Icària.

Mead, D. and Morrison, C. (1996). The informal sector elephant. World Development, 24(10): 1611-1619.

Mitchell, D. (1995). The end of public space? People's Park, definitions of the public, and democracy. Annals of the Association of American Geographers, 85(1): 108-133.

Moser, C.O.N. (1978). Informal Sector or Petty Commodity Production: Dualism or Dependence in Urban Development? World Development, 6(9-10): 1041-1064.

Neal, Z.P. (2010). Locating public space. In Common ground? Readings and reflections on public space. A.M. Orum y Z.P. Neal. New York: Routledge.

Newman, O. (1972). Defensible space: Crime prevention through urban design. New York: McMillan.

Park, R.E.; Burgess, E.W. and McKenzie, R.D. (1992) [1925]. The City. University of Chicago Press.

Pérez Sáinz, J.P. (1991). Informalidad urbana en América Latina. Enfoques, problemáticas e interrogantes. Guatemala:

Portes, A.; Castells, M. and Benton, L. (Eds.) (1989). The Informal Economy: studies in advanced and less developed countries. Baltimore: The Johns Hopkins University Press.

Portes, A. and Haller, W.J. (2004). La economía informal. Santiago de Chile: CEPALNaciones Unidas.

Porras Bulla, J. (2016). Otros trabajos y otros trabajadores en Barcelona. Polis. Revista Latinoamericana, 45. In: http://journals.openedition.org/polis/12124.

Rakowski, C.A. (1994). The informal sector debate, part 2: 1984-1993. In Contrapunto: The informal sector debate in Latin America. C.A. Rakowski, Ed. New York: State University of New York Press.

Salcedo, M.T. (2000). Escritura y territorialidad en la cultura de la calle. In Antropologías transeúntes. E. Restrepo y M.M.V. Uribe, Comps. Bogotá: Instituto Colombiano de Antropología e Historia.

Saavedra J. and Chong, A. (1999). Structural reform, Institutions and Earnings: Evidence from the formal and Informal sectors. The journal of development studies, 35(4): 95110.

Staeheli, L.A. and Thompson, A. (1997). Citizenship, Community, and Struggles for Public Space. The Professional Geographer, 49(1): 28-38.

Taussig, M. (2015). La magia del Estado. México D. F.: Universidad Nacional Autónoma de México, Dirección General de Artes Visuales-Instituto de Investigaciones Estéticas, Siglo XXI Editores.

Valenzuela, A. (2003). Day labour work. Annual review of Sociology, 29(1): 307-333.

Wacquant, L. (2007). Los condenados de la ciudad. Gueto, periferias y Estado. Buenos Aires: Siglo XXI Argentina. 